\title{
Sectoral optimisation of India's foreign direct investment inflows - does it support economic development?
}

\section{D.K. Malhotra*}

School of Business Administration,

Philadelphia University,

Philadelphia, PA 19144, USA

Email: malhotrad@philau.edu

*Corresponding author

\section{Faraji Kasidi}

Institute of Accountancy Arusha,

Arusha, Tanzania

Email: fkasidi@gmail.com

\section{Rahul Singh and G.N. Patel}

Birla Institute of Management and Technology, Greater Noida, UP 201306, India

Email: rahul.singh@bimtech.ac.in

Email: gn.patel@bimtech.ac.in

\begin{abstract}
Due to insufficient domestic savings, emerging market policy makers look to foreign direct investment (FDI) to increase investment and capital formation. Irving Fisher (1930s) argued that economy without money stagnates; so if flow of money slows down in domestic market it needs policy initiatives from policy makers to attract FDI. The study seeks to put forth mathematical arguments for optimising foreign direct investment (FDI) inflows to emerging market economies in the context of India. We use primal and dual linear programming techniques with regard to the sectoral FDI inflows to India for the period 2002-2010. The study shows that FDI inflows during the period are not optimally utilised and, consequentially, require intervention for improving its optimal solutions potentials.
\end{abstract}

Keywords: foreign director investment; capital allocation; variance-covariance matrix; VCM; optimisation model; data envelopment analysis; DEA; India; FDI inflow; economic policy.

Reference to this paper should be made as follows: Malhotra, D.K., Kasidi, F., Singh, R. and Patel, G.N. (2016) 'Sectoral optimisation of India's foreign direct investment inflows - does it support economic development?', Int. J. Business Intelligence and Systems Engineering, Vol. 1, No. 1, pp.99-120. 
Biographical notes: D.K. Malhotra has published over 100 research articles in such journals as Omega - The International Journal of Management Science, International Journal of Business, Financial Counseling and Planning, European Journal of Operational Research, Journal of Financial Research, Financial Review, European Journal of Finance, Quarterly Journal of Business and Economics, Journal of Economics and Finance, Journal of Multinational Financial Management, Journal of Retail Banking, The Real Estate Finance Journal, The International Journal of Finance, Journal of Intelligent Systems, Advances in Futures and Options Research, Journal of Commercial Lending, Journal of Global Business and Journal of Lending and Credit Risk Management. In addition, he has presented over 100 research papers at various academic conferences all over the world. New York Times, Investor's Business Daily, and Philadelphia Inquirer have quoted Dr. Malhotra on such wide ranging topics as mutual fund expenses, declining value of euro, and merger of Cores State Bank with First Union Bank.

Faraji Kasidi is a Faculty in Economics and International Finance and deputy rector at Institute of Accountancy at Arusha, Tazania. He has published extensive in Journal of Applied Economic Research, International Business Research, Advances in Management and Applied Economics and he is widely referenced.

Rahul Singh conducts research in strategic management, emerging market, cross-cultural management, and emerging multinationals. He has published in many journals including Journal of Business Research, Journal of Brand Management, International Journal of Emerging Market, Journal of Global Scholars of Marketing Science, Journal of Applied Economic Research, Journal of Business Perspectives, International Journal of Cross Cultural Competence and Management, Asia Pacific Journal of Finance and Banking and Journal of Insurance and Risk Management. He has also been the Editor-in-Chief of two journals and reviewer of several international journals. His research and consultancy assignments include organisations such as Bank for International Settlement, European Union, and USAID.

Gokulananda N. Patel is a Professor in Decision Science and heading the area of Operations, IT and Decision Sciences at Birla Institute of Management Technology, Greater Noida. His research interest lies in mathematical programming, efficiency measurement. He has published more than 150 papers in both international and national journals of repute.

\section{Introduction}

Foreign direct investment (FDI) is believed to facilitate capital and economic growth in emerging markets by providing new technologies, management techniques, finance and market access for the production of goods and services. However, attracting FDI is a major challenge for host countries as they need to identify the major drivers of push and pull factors that attract FDI. Over the last two decades, emerging markets in general and BRIC countries in particular have persistently devoted a great deal of energy and attention to encourage FDI inflows to boost capital formation in their respective economies that will help them break their 'vicious circle of poverty' and launch them on the path to economic growth and prosperity. FDI is a considered a growth initiator by bringing it much needed capital, knowledge, and technology. Therefore, emerging 
markets compete to attract more FDI flows to a country to promote domestic economic development, because FDI capital flows will supplement domestic capital stock and provide knowledge and technological spillovers for local industries, and help accumulate and improve human capital (Blomström et al., 1994; OECD, 2007, 2010; Zhang, 2008).

The theory that underpins capital movement asserts that accumulation of capital leads to economic growth (Chakravarty, 1993; Lewis, 1958; Joshi and Little, 1997; Panchamukhi, 1998; Jones, 1998; Barro and Sala-i-Martin, 2004). Singh and Zammit (1998) argue that liberalisation of trade and capital movements, and the associated phenomena of the globalisation of markets and production, leads to a more efficient allocation of the world's resources and faster world growth rates.

With liberalisation of Indian economy in 1991, many sectors of the Indian economy opened up for private investment. Open trade regime replaced import substitution and protectionism. The globalisation also supported large investment in the country by foreign countries. Sectoral restrictions on FDI inflows have been progressively reduced and foreign investment ceilings in various sectors of Indian economy have been steadily raised. Consequently, Government of India (2010) recorded sectoral FDI inflows from 2002-2010 as given in Figure 1.

Figure 1 Sectoral FDI inflows to India for 2002-2010 (see online version for colours)

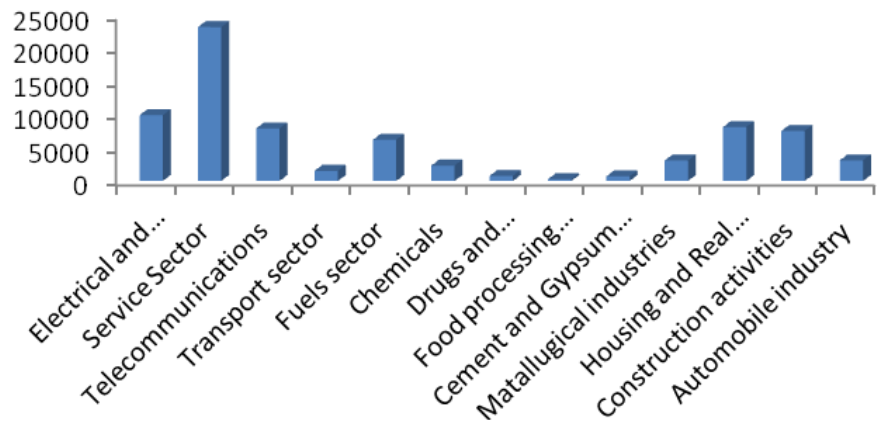

Source: Research study, 2010, DIPP Annual Report 2010

Figure 1 indicates that the service sector attracted more capital than any other sector, and the least attractive sector was food and processing industry. Figure 1 shows not only the sectoral patterns of the FDI in India, but also reflects on the policy reforms in few sectors which received higher attention of the investors. This pattern of investment in terms of sectoral attractiveness brings sectoral conflicts and inefficiency (Chakravarty, 1993; Altman, 2000). The capital allocation, on one hand, offers competitive edge in capacity building in a sector and at the same time, it disturbs the economic activity and allocation of other national resources in the economy. These sectoral conflicts and inefficiencies could be mitigated by formulating a sectoral development pattern by optimising FDI inflows.

This paper provides the rationale and model to optimise FDI inflows in India to avoid sectoral conflicts and inefficiency that are caused by market mechanism or policy direction in resource allocation. This paper will help policy makers to make an informed judgement in the policy reforms for opening the sectors.

Rest of the paper is organised as follows. In Section 2, we provide a review of previous literature. Section 3 discusses the data sources, methodology, and model used in 
this study. Section 4 discusses the empirical results and Section 5 provides summary and conclusions.

\section{Literature review}

The sectoral capital flow volatility and sectoral FDI resource distribution can cause difficulties and discontent in the economy as a whole. The difficulties may be to the tune of disasters as has been observed in case of East Asian Crisis of 1997. The rationale which justifies government allocation of resources, contrary to Adam Smith's invisible hand and Milton Friedman's efficient market postulates, has been that markets can be bad masters but can be good slaves (Chakravarty, 1993; Joshi and Little, 1997; Stiglitz, 1999, 2009; Roubini and Mihm, 2010; Fox, 2010). Chakravarty (1993) observed that inefficiency in the use of resources becomes one of the reasons for stagnation in many developing countries. Efficient allocation of resources should be planned to avoid sectoral conflicts.

Mohamed and Youssef (2004) asserted that optimal selection of production, distribution, and investment decisions are interrelated. Investments in the markets are done to support the production and distribution activities. The resource allocation may demand the policies should be reworked to attract FDI towards those sectors that are not receiving the FDI for a balanced economic growth.

Several studies illustrate the use of linear programming (LP) in policy decisions. Wadley and Smith (1998) showed the use of LP by town planners in land allocation. Also, LP has been applied in important process in speech recognition, natural language parsing, information retrieval and machine translation. Candes and Tao (2004) applied LP in decoding linear codes problem successfully. Dynamic linear programming (DLP) has been used for developing optimisation methods, and can address to the large scale problems such as ecological problems, economic models, and large organisations systems (Propoi, 1976). Dempster and Hutton (1996) argued that given the present state of LP solver and computer technology, it is efficient to solve the complex problems of financial and derivatives markets.

Sharma (2008) studied cement firms in India by applying data envelopment analysis (DEA) and scale efficiency. She found that $50 \%$ firms are found to be technically efficient and they are also operating at optimum plant size. Whereas $25 \%$ firms have demonstrated decreasing returns to scale (DRTS) inferring over utilisation of their plant capacities and the rest $25 \%$ are showing increasing returns to scale (IRTS) which implies to underutilisation of cement plants.

\section{Data sources, methodology and model}

We obtain data on FDI flows and sectoral flows to India for the period 2002 to 2010 . This is time period high growth rate in Indian economy (Pradhan, 2008). Sources of data are Government of India's (GOI), Reserve Bank of India (RBI), Department of Industrial Policy and Promotion (DIPP) and Economic Survey publications that are publically accessed. Economic Survey and IMF database were used to obtain the data on gross 
domestic product (GDP) at current prices for Indian economy. The study also used IMF database for GDP at current prices because Economic Survey data are not published in current prices. Table 1 provides a list of the data sources used in this study.

Table 1 Summary of data sources for the study

\begin{tabular}{ll}
\hline SN & Sources of data \\
\hline 1 & Department of Industrial Policy and Promotion (DIPP), Government of India's (GOI) \\
2 & Reserve Bank of India (RBI) \\
3 & Economic Survey \\
4 & International Monetary Fund (IMF) \\
\hline
\end{tabular}

\subsection{Hypotheses of the study}

Previous studies show that the main driver of FDI in any country is economic growth of that country (Malhotra et al., 2014; Lecraw, 1984). Several studies on emerging markets have focused on the determinants of FDI in the context of emerging markets and the role of FDI in influencing growth in emerging markets. Bhavan et al. (2011) investigated the determinants and growth effects of FDI in four South Asian countries. They found that FDI is having a positive impact on growth in four South Asian countries. Hakro and Ghumro (2011) found that stable macro-economic policies and improvement in risk profile of the country are important factors in determining FDI in Pakistan. Ho and Rashid (2011) reported that the rate of economic growth and degree of openness are the two main determinants of FDI in Indonesia, Malaysia, the Philippines, Singapore and Thailand. Angelo et al. (2010) suggested that policy makers in emerging markets should stimulate internal demand to attract FDI into those markets. Artige and Nicolini (2006) and Kolstad and Villanger (2008) and Xing (2006) studies the role of GDP growth rate influencing the level of FDI flows. While higher GDP growth rate in India since economic liberalisation of 1991 is attracting more FDI to India, Indian Government policies with regard to a particular sector are influencing the sectoral allocation of FDI to different sectors in India. The Indian government policy reforms for each sector are influenced by several factors such as regulatory issues, market size, and economic growth. The proposed hypothesis studies the scope and ability of Indian economy for optimised allocation of FDI.

$\mathrm{H}_{0} \quad$ FDI inflows in Indian economy cannot optimally be maximised.

$\mathrm{H}_{1} \quad$ FDI inflows in Indian economy can optimally be maximised.

The study uses LP technique for optimising FDI inflows to India. Assumptions of LP techniques are illustrated in Taylor (2008), Taha (2002) and Hillier and Lieberman (2010). The study also uses dual solution of the primal solution for optimal solution testing. Dual solution becomes litmus test for the solutions obtained in the primal problem. General statement of LP problems becomes:

$$
\text { Maximise } Z=\sum_{j=i}^{n} c_{j} x_{j}
$$


Table 2 FDI flows to various sectors of Indian economy for 2002 to 2010

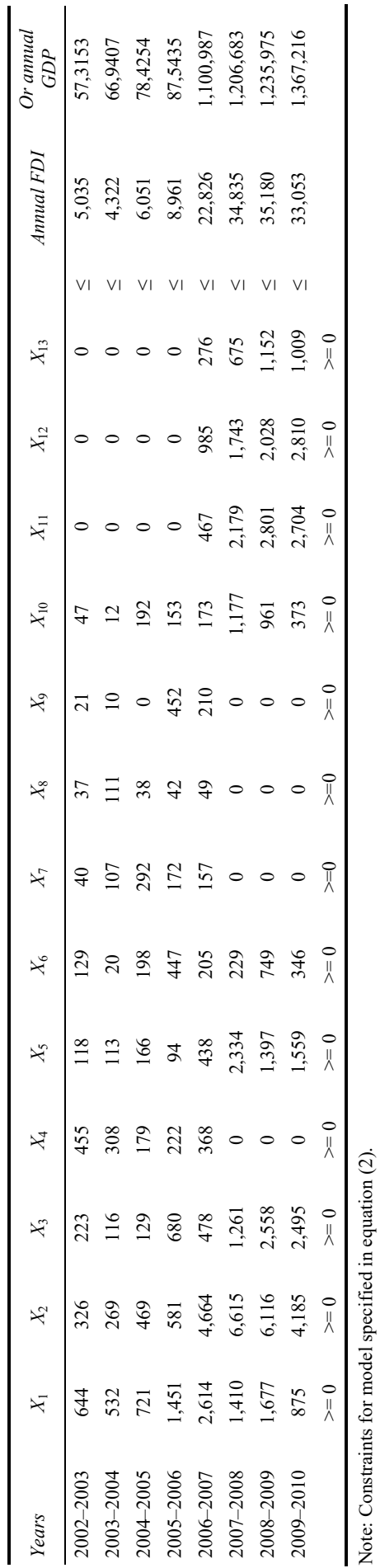


Subject to

$$
\begin{array}{ll}
\sum_{j=1}^{n} a_{i j} x_{j} \leq b_{i} & \text { for } i=1,2, \ldots, m \\
X_{j} \geq 0 & \text { for } j=1,2, \ldots, n
\end{array}
$$

where $Z$ is the value of the overall performance of FDI inflows in Indian economy from 2002-2010; $x_{j}$ 's are sectors of the economy for which attracted FDI inflows above the threshold of US $\$ 1$ million in respective year (i.e., for $j=1,2, \ldots, 13$ ); $c_{j}$ 's are coefficients representing per unit contribution of FDI inflows to the sectors of the economy $\left(x_{j}{ }^{\prime} \mathrm{s}\right)$ to the value of the objective functions; $a_{i j}$ 's are technological coefficients or input-output and represents actual FDI inflows to sectors of the economy in respective year; $b_{i}$ 's are total annual FDI inflows to the economy (i.e., for $i=1,2, \ldots, 8$ ); $n$ 's are number of decision variables $x_{1}, x_{2}, \ldots, x_{13}$ whose respective values are to be determined, they show activities of the economy; and ms show resource availability.

Specifically, the research problem model is given by equation (2):

$$
\text { Maximise } Z=c_{1} x_{1}+c_{2} x_{2}+\ldots+c_{13} x_{13}
$$

Subject to constraints summarised in Table 2.

Where $X_{1}$ is electrical equipment including computer software and electronics sector, $X_{2}$ is service sector (financial and non-financial), $X_{3}$ is telecommunications sector (radio paging, cellular mobile, basic telephone services), $X_{4}$ is transportation sector, $X_{5}$ is fuels sector (power, petroleum, natural gas and oil refinery), $X_{6}$ chemicals sector (other than fertilisers), $X_{7}$ is drugs and pharmaceuticals sector, $X_{8}$ is food processing sector, $X_{9}$ is cement and gypsum products sector, $X_{10}$ is metallurgical sector, $X_{11}$ is housing and real estate sector, $X_{12}$ is construction sector (including roads and highways), and $X_{13}$ is automobile sector.

Before computing optimal FDI inflows, values of $C_{j}$ 's are estimated accordingly. Hillier and Lieberman (2010), Wadley and Smith (1998) purported that it is very difficult to estimate objective function for a practical optimisation problem. However, there are several methods that can be applied in estimating objective function. Some of them are ordinary linear squares (OLS) regression equation, Pareto optimality, Ramsey optimality, means testing, input output approach, DEA, fuzzy approach to name a few. Moreover, researchers estimated $C_{j}$ 's using variance-covariance matrix (VCM) because of its merits articulated below.

\subsection{Variance-covariance approach}

The standard Markowitz (1952) mean-variance approach was developed for portfolio selection. It is mostly applied in a quadratic programming problem where either the total variance is minimised at a given level of return or portfolio return is maximised subject to a given level of portfolio risk/variance (Ostermark, 2005). Due to problems of statistical inferences on the mean-variance approach, Friedman and Meiselman developed variance-covariance approach (VCA) in 1963 originating from simple form model of the quantity theory of money (Witkovsky, 1996). The VCA has been extensively used in estimating objective function. The algorithm for estimating optimal objective function is as follows. 
where $X^{\prime}$ s are actual sectoral FDI inflows to India and $X^{\prime}$ are the transpose. Brook (2010) illustrates that $X$ 's may be imported from original variable (i.e., sectoral FDI inflows).

$$
\begin{aligned}
& \left(X^{\prime} X\right)^{-1} \\
& \hat{\beta}=\left[\begin{array}{c}
\hat{\beta}_{1} \\
\hat{\beta}_{2} \\
\vdots \\
\hat{\beta}_{13}
\end{array}\right]=\left(X^{\prime} X\right)^{-1}\left(X^{\prime} Y\right)
\end{aligned}
$$

where $Y$ is total annual FDI inflows that need to be maximised. Equation (5) is optimal policy objective function. $Y$ is the annual FDI inflows for maximisation.

\section{Data analysis and discussion}

The fundamental economic problem is to estimate optimal sectoral FDI inflows that would maximise GDP for economic development. Whereas $\beta$ represents estimated optimal sectoral FDI inflows that would maximise GDP. Optimal sectoral FDI inflows $(\beta)$ may be estimated by substituting values of $X$ 's (actual sectoral FDI inflows) in algorithms summed as equations (3) to (5) of the VCM. The first algorithm step is presented below and intends to estimate objective function.

Substituting values of Xs (actual sectoral FDI inflows to India) which are in constraints inequalities of equation (3) in equation (5), estimated objective function is:

Table 3 A summary of the original sectoral FDI inflows to India during the period 2002 to 2010, labelled as matrix $X$ in step 1

\begin{tabular}{lccccccccccccc}
\hline Years & $X_{1}$ & $X_{2}$ & $X_{3}$ & $X_{4}$ & $X_{5}$ & $X_{6}$ & $X_{7}$ & $X_{8}$ & $X_{9}$ & $X_{10}$ & $X_{11}$ & $X_{12}$ & $X_{13}$ \\
\hline $2002-2003$ & 644 & 326 & 223 & 455 & 118 & 129 & 40 & 37 & 21 & 47 & 0 & 0 & 0 \\
$2003-2004$ & 532 & 269 & 116 & 308 & 113 & 20 & 107 & 111 & 10 & 12 & 0 & 0 & 0 \\
$2004-2005$ & 721 & 469 & 129 & 179 & 166 & 198 & 292 & 38 & 0 & 192 & 0 & 0 & 0 \\
$2005-2006$ & 1,451 & 581 & 680 & 222 & 94 & 447 & 172 & 42 & 452 & 153 & 0 & 0 & 0 \\
$2006-2007$ & 2,614 & 4,664 & 478 & 368 & 438 & 205 & 157 & 49 & 210 & 173 & 467 & 985 & 276 \\
$2007-2008$ & 1,410 & 6,615 & 1,261 & 0 & 2,334 & 229 & 0 & 0 & 0 & 1,177 & 2,179 & 1,743 & 675 \\
$2008-2009$ & 1,677 & 6,116 & 2,558 & 0 & 1,397 & 749 & 0 & 0 & 0 & 961 & 2,801 & 2,028 & 1,152 \\
$2009-2010$ & 875 & 4,185 & 2,495 & 0 & 1,559 & 346 & 0 & 0 & 0 & 373 & 2,704 & 2,810 & 1,009 \\
\hline
\end{tabular}

Step 1

Matrix $X$ [as theorised by Cuthbertson and Nitzsche (2004), Sharpe et al. (2006) and Rardin (2002)] shows the original sectoral FDI inflows to India 2002-2010. Step 1 presents actual variables (i.e., actual annual sectoral FDI inflows) as recorded and published by Government of Agency (DIPP, 2010). Presentation of the actual FDI inflows during the period is shown in Table 3. Matrix algorithms are used to 
estimate optimal FDI inflows that will maximise GDP for economic development (see Cuthbertson and Nitzsche, 2004; Sharpe et al., 2006; Rardin, 2002).

No change in the arrangement and alignment is required for VCM approach. There are 13 sectors for the study, which have been one of the top ten recipients of FDI inflows from 2002-2010 (DIPP, 2010). The second step is to calculate the VCM as illustrated below.

To optimise our variables, transpose of matrix is computed as shown in Table 4. The transposed main diagonals in the lower-right are variances in the respective sectors and elements in the off-diagonals are covariance.

Step 2

This step provides VCM $X^{\prime} X$ and it is the basis for symmetric matrix and optimal objective policy function.

To solve optimisation problem, algorithm requires computing matrix transpose which is a mirror to the original matrix (Chiang and Wainwright, 2005). Miller and Miller (2008) postulated that if there is a high probability that large values of $X$ will go with large values of $Y$ and small values of $X$ with small values of $Y$, the covariance will be positive; if there is high probability that large values of variable $X$ will go with small values of $Y$, and vice versa, the covariance will be negative. Step 2 reveals that service sector (financial and non-financial) has a high variance of USD 121,166,961 followed by housing and real estate sector with variance USD 20,123,347. However, the sectors with smallest variance are food processing sector and drugs and pharmaceuticals sectors with USD19, 299 and USD 152,546, respectively.

Mathematically, it is imperative to know as to whether variance-covariance matrix (VCM) has a solution or not. Step 3 aimed at determining as to whether feasible solution by taking its inverse.

\section{Step 3}

To calculate the $\left(X^{\prime} X\right)^{-1}$ - to prove that VCM has feasible solution (i.e., feasible optimal solution that will maximise GDP for economic development), its inverse shall have nonzero determinant as shown in Table 5.

The determinant of the values presented in Table 4 is non-zero and it suggests that VCM has a feasible solution that helps estimate optimal sectoral FDI inflows.

So far, the study has been estimating optimal FDI inflows that will maximise GDP $(Y)$. The next step is to optimise sectoral FDI inflows for economic growth. Step 4 estimates optimal sectoral FDI inflows for economic growth.

\section{Step 4}

To calculate $X^{\prime} Y$ - in this study, there are two optimal possible variables to optimise. First, is to optimise sectoral FDI inflows for its own outcomes, and second is to optimise sectoral FDI inflows for economic growth. Equation (6) optimises sectoral FDI inflows for its own outcomes, and equation (7) optimises sectoral FDI inflows for economic growth. The study optimised both variables because the study of macroeconomics more or less hinges on optima. In the matrix format, $X^{\prime} F D I$ is presented as follows. 


$$
X^{\prime} Y=\left(\begin{array}{l}
219,609,775 \\
701,229,962 \\
235,793,654 \\
15,094,540 \\
194,908,081 \\
56,382,323 \\
7,555,720 \\
2,390,811 \\
8,992,787 \\
93,907,776 \\
274,479,699 \\
247,424,985 \\
103,691,438
\end{array}\right)
$$

$X^{\prime} Y$ where $Y$ is total annual economic growth (GDP)

$$
X^{\prime} Y=\left(\begin{array}{l}
10,409,385,498 \\
27,641,594,695 \\
9,522,655,916 \\
1,206,853,223 \\
7,512,529,346 \\
2,534,761,367 \\
646,984,616 \\
216,029,123 \\
645,634,175 \\
3,627,969,583 \\
10,302,441,225 \\
9,536,154,924 \\
3,921,747,581
\end{array}\right)
$$

Whereas equation (6) optimises FDI inflows, equation (7) optimises GDP for economic development. Both equations (6) and (7) provide practical problems which confront policy makers as to whether maximise FDI inflows or to maximise its intended outcome (GDP). These optimal solutions are usually provided to decision maker with range of options to select the best solution that fits the objective(s).

Step 5(a) and step 5(b) estimates optimal sectoral coefficients which shall optimise FDI inflows or GDP. If economic policy makers were to maximise FDI inflows, the corresponding sectoral coefficients are estimated in equation 5(a) and if it were to maximise GDP, sectoral coefficients are estimated in equation 5(b). 
Table 4 VCM on the basis of Table 2 and it is the basis for symmetric matrix and optimal objective policy function

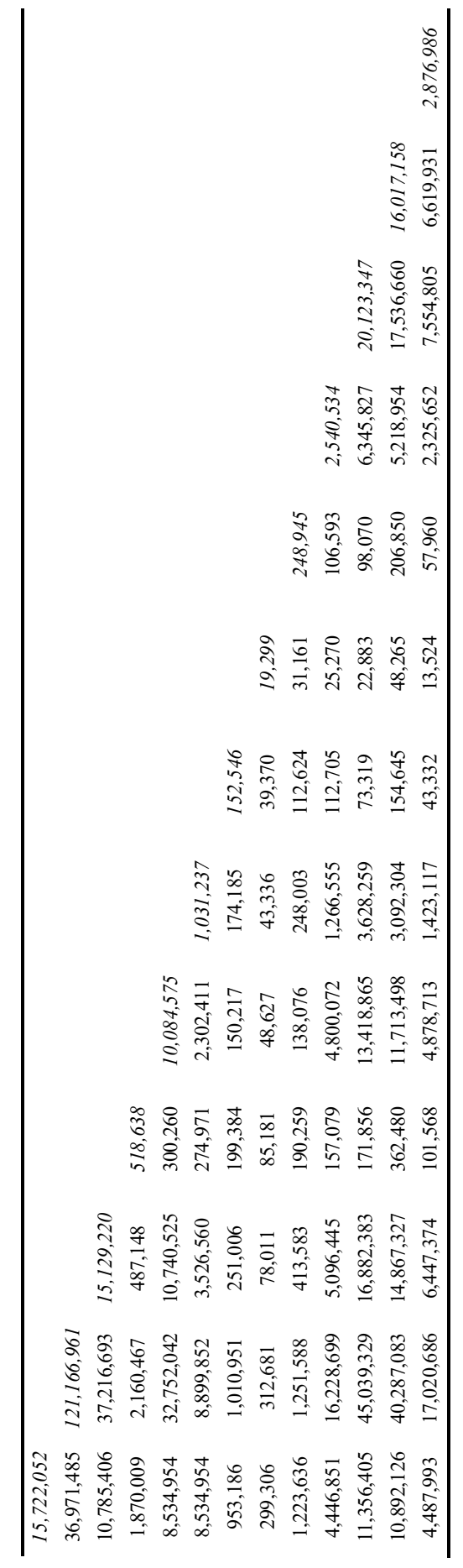


Table 5 A summary of the results of $\left(X^{\prime} X\right)^{-1}$

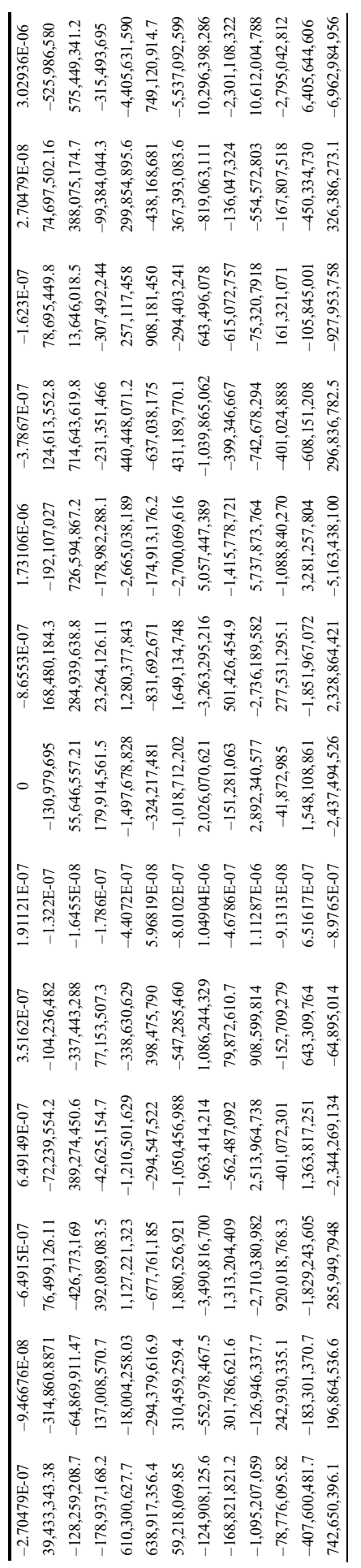




\section{Step 5(a)}

To calculate $\left[X^{\prime} X\right]^{-1} X^{\prime} F D I$ - this step provides objective sectoral FDI inflows function that optimises total annual FDI inflows.

$$
\left(\hat{\beta}_{1-13}\right)=\left(\begin{array}{l}
64.46 \\
-16 \\
-48 \\
112 \\
128 \\
112 \\
-128 \\
384 \\
-32 \\
-256 \\
0 \\
0 \\
128
\end{array}\right)
$$

OR

\section{Step $5(b)$}

This step provides objective sectoral FDI inflows function that optimised GDP during the period of the study.

$$
\left(\hat{\beta}_{1-13}\right)\left(\begin{array}{l}
2,318.764 \\
-512 \\
-3,840 \\
5,120 \\
6,144 \\
4,096 \\
0 \\
16,384 \\
2,048 \\
-8,192 \\
0 \\
-4,096 \\
8,192
\end{array}\right)
$$


Equations (8) and (9) provide the optimal solutions. These optimal solutions are usually provided to decision maker with range of options to select the best solution that fits the economic development policy objective(s). Solutions (8) and (9) provide optimal policy objective functions for FDI inflows and GDP in the period of the study.

If the government were to optimise FDI inflows for economic development then, it should attract FDI inflows in identified sectors as follows:

$X_{1} \quad$ electrical equipment including computer software and electronics sector

$X_{2} \quad$ service sector including financial and non-financial

$X_{3}$ telecommunications sector including radio paging, cellular mobile, basic telephone services

$X_{4} \quad$ transportation sector

$X_{5} \quad$ fuels sector including power, petroleum, natural gas and oil refinery

$X_{6} \quad$ chemicals sector including other than fertilisers

$X_{7}$ drugs and pharmaceuticals sector

$X_{8} \quad$ food processing sector

$X_{9} \quad$ cement and gypsum products sector

$\mathrm{X}_{10}$ metallurgical sector

$X_{11}$ housing and real estate sector

$X_{12} \quad$ construction sector including roads and highways

$X_{13}$ automobile sector.

To maximise FDI inflows or GDP the study uses applied LP approach. In economic reasoning, solution (8) is not economically useful. It is impractical to attract FDI for the sake of FDI inflow without channelling it into productive outcomes. If FDI inflows are attracted for the sake of FDI inflows, this would mean that the capital (FDI) borrowed with interest attached to it cannot service its debt payment when due. Hence, solution (9) becomes more useful for furthering the study.

While FDI inflows to India come from different countries, which are channelled to respective sectors for productive outcomes, solution (9) becomes optimal policy objective function for equation (2) and (3). So, step 6 applied LP approach to obtain optimal FDI inflows allocation to India across sectors for economic development.

\section{Step 6(a)}

To maximise FDI inflows:

$$
\begin{aligned}
\operatorname{Max} \mathrm{FDI} & =2,318.8 X_{1}-512 X_{2}-3,840 X_{3}+5,120 X_{4}+6,144 X_{5} \\
& +4,096 X_{6}+0 X_{7}+16,384 X_{8}+2,048 X_{9}-8,192 X_{10} \\
& +0 X_{11}-4,096 X_{12}+8,192 X_{13}
\end{aligned}
$$

Subject to the constraints specified in Table 6 . 
Table 6 Linear programming for maximising FDI

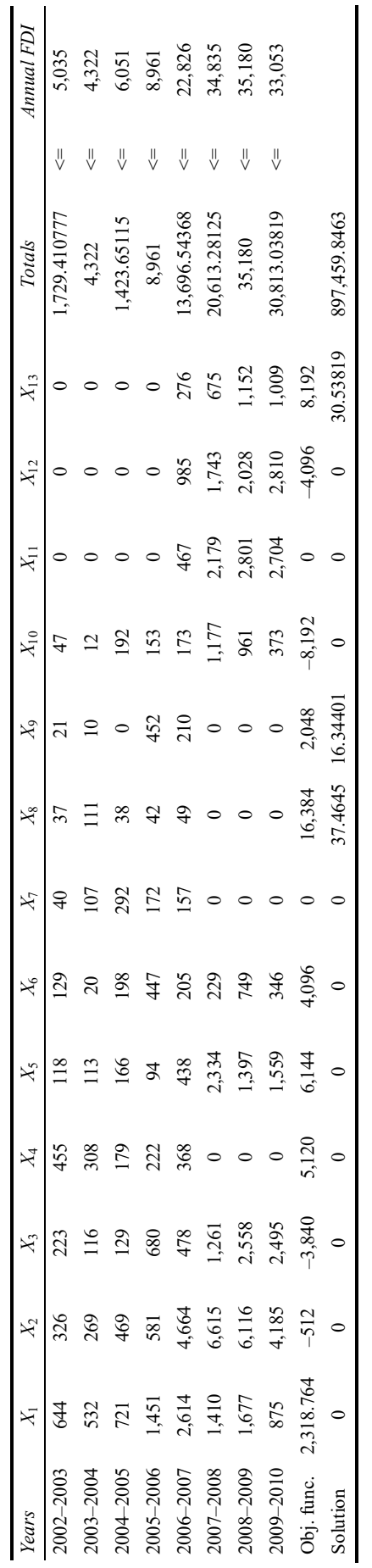


Table 7 LP maximising FDI inflows for GDP

\begin{tabular}{|c|c|}
\hline 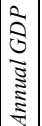 & 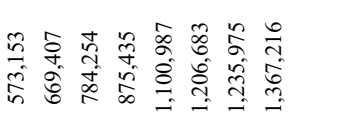 \\
\hline $\begin{array}{c}5 \\
5 \\
5 \\
5 \\
5\end{array}$ & 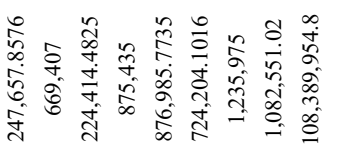 \\
\hline$\stackrel{m}{\star}$ & 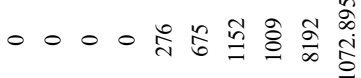 \\
\hline 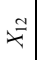 & ○ 000 \& \\
\hline$\equiv$ & 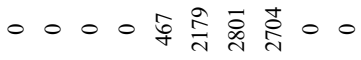 \\
\hline 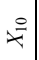 & 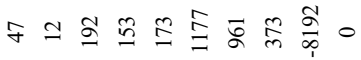 \\
\hline 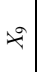 & $\bar{\lambda} \varrho 0 \tilde{\gamma} \stackrel{N}{\pi} 0$ \\
\hline$\leftarrow^{\infty}$ & 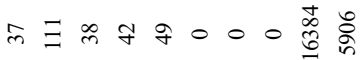 \\
\hline$\star$ & q \\
\hline 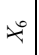 & 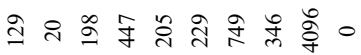 \\
\hline$\approx$ & 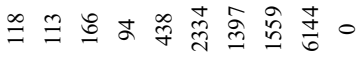 \\
\hline$\star$ & 字 \\
\hline 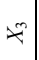 & તిస \\
\hline$\mp$ & 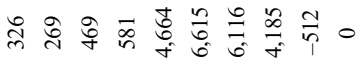 \\
\hline 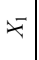 & 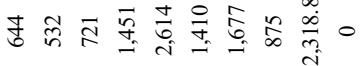 \\
\hline 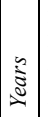 & 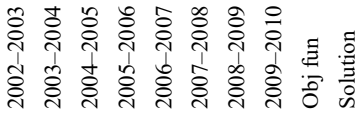 \\
\hline
\end{tabular}


Mathematically, optimal policy objective function 6(a) is maximised by satisfying all inequalities by investing USD 37.4645 million in food processing sector $\left(X_{8}\right)$, USD 16.34401 million in cement and gypsum sector $\left(X_{9}\right)$ and USD 30.53819 million in automobile industries sector $\left(X_{13}\right)$. While the mathematical, interpretation of the zeros in the rest of the sectors of the economy is not to allocate funds in those sectors, economic interpretation is different.

Our analysis shows that total maximum FDI inflows to India from 2002-2010 could have been USD 897,459.8463 million. The maximum optimal FDI inflows USD $897,459.8463$ million is much higher compared to actual total FDI inflows of USD 150,263 million from 2002-2010. Baumol (2002) explains that number is big because LP uses standard calculation of the arithmetic of permutations and combinations. If the economy was to maximise FDI inflows for economic growth, the mathematical computation would have been to incorporate solution (9) subject to the constraints as demonstrated in step 6(b).

Step 6(b)

To maximise GDP

$$
\begin{aligned}
\operatorname{Max} \mathrm{GDP} & =2,318.8 X_{1}-512 X_{2}-3,840 X_{3}+5,120 X_{4}+6,144 X 5 \\
& +4,096 X_{6}+0 X_{7}+16,384 X_{8}+2,048 X_{9}-8,192 X_{10} \\
& +0 X_{11}-4,096 X_{12}+8,192 X_{13}
\end{aligned}
$$

Subject to constraints specified in Table 7.

The optimal policy objective function 6(a) is maximised by satisfying all inequalities by investing USD 5,905.644 million in food processing sector $\left(X_{8}\right)$, USD 1,388.049 million in cement and gypsum sector $\left(X_{9}\right)$ and USD 1,072.895 million in automobile industries sector $\left(X_{13}\right)$. Whereas mathematical, interpretation of the zeros in the rest of the sectors of the economy is do not allocate funds in those sectors, economic interpretation is different and the study refers comprehensive economic interpretation of the in the sensitivity analysis section below.

Total maximum GDP to India from 2002-2010 could have been USD 108,389,954.8 million. The maximum optimal GDP of USD 108,389,954.8 million is much higher compared to actual total GDP of USD 7,813,110 million from 2002-2010. Ravindra et al. (2001) postulated that the solution of a practical problem is not complete with mere determination of the optimal solution; it needs to be substantiated by sensitivity analysis.

\subsection{Sensitivity and dual analysis}

As this study uses FDI inflows which are time bound, some of the variables will change over time and thus, the study steers to sensitivity and dual analysis. According to Lawrence and Pasternack (2004), one of the biggest drawbacks of integer linear programming (ILP) is lack of sensitivity analysis. Insensitivity occurs when there is no pattern to disjoint effects of changes in the optimal objective function and the resources available. It also means that when changes occur in the resources available, they occur in large discreet capital flow jumps rather than through the smooth, marginal changes. 
In step 6(a) and 6(b), LP by Microsoft excel produced zero values for $X_{1}$ - electrical equipment including computer software and electronics sector, $X_{2}$ - service sector, $X_{3}$ - telecommunications sector, $X_{4}$ - transportation industry, $X_{5}$ - fuels sector, $X_{6}$ - chemicals sector, $X_{7}$ - drugs and pharmaceuticals sector, $X_{10}$ - metallurgical industries, $X_{11}$ - housing and real estate sector and $X_{12}$ - construction activities (including roads and highways) sector.

Researchers find it logical and reasonable to incline the optimal problem with unbounded solution or ILP than to mistaken modelling of the linear problem. Chakravaty (1993) and Ravindra et al. (2001) urged that the study has to analyse researchable variables beyond optimal solutions, arguing for sensitivity analysis or post-optimal analysis so that a decision maker could have a range of solutions. But these optimal solutions did not provide the sensitivity report because the optimal solution is unbounded or ILP optimal solution. To circumvent this problem, economic theory provides an option to sensitivity analysis. Zavadskas et al. (2007) and Takayama (2006) showed that dual solution of primal problem provides sensitivity analysis of the primal optimal model. Here, the dual value could be interpreted as the maximum price an economy pays for additional unit of FDI inflows in a year.

Step 7(a)

Dual optimal solution for FDI inflows

$$
\begin{aligned}
\text { Min Annual FDI } & =5,035 Y_{1}+4,322 Y_{2}+6,051 Y_{3}+8,961 Y_{4}+22,826 Y_{5} \\
& +34,835 Y_{6}+35,180 Y_{7}+33,053 Y_{8}
\end{aligned}
$$

Subject to

Table 8 Dual optimal of FDI inflows for GDP

\begin{tabular}{lccccccccccc}
\hline & $Y_{1}$ & $Y_{2}$ & $Y_{3}$ & $Y_{4}$ & $Y_{5}$ & $Y_{6}$ & $Y_{7}$ & $Y_{8}$ & Usage & Resources \\
\hline$X_{1}$ & 644 & 532 & 721 & 1,451 & 2,614 & 1,410 & 1,677 & 875 & $330,940.7535$ & $\geq$ & $2,318.8$ \\
$X_{2}$ & 326 & 269 & 469 & 581 & 4,664 & 6,615 & 6,116 & 4,185 & $282,778.4347$ & $\geq$ & -512 \\
$X_{3}$ & 223 & 116 & 129 & 680 & 478 & 1,261 & 2,558 & 2,495 & $73,358.27857$ & $\geq$ & $-3,840$ \\
$X_{4}$ & 455 & 308 & 179 & 222 & 368 & 0 & 0 & 0 & $77,286.72194$ & $\geq$ & 5,120 \\
$X_{5}$ & 118 & 113 & 166 & 94 & 438 & 2,334 & 1,397 & 1,559 & $99,492.92319$ & $\geq$ & 6,144 \\
$X_{6}$ & 129 & 20 & 198 & 447 & 205 & 229 & 749 & 346 & $89,182.25237$ & $\geq$ & 4,096 \\
$X_{7}$ & 40 & 107 & 292 & 172 & 157 & 0 & 0 & 0 & $125,215.1206$ & $\geq$ & 0 \\
$X_{8}$ & 37 & 111 & 38 & 42 & 49 & 0 & 0 & 0 & 16,384 & $\geq$ & 16,384 \\
$X_{9}$ & 21 & 10 & 0 & 452 & 210 & 0 & 0 & 0 & 2,048 & $\geq$ & 2,048 \\
$X_{10}$ & 47 & 12 & 192 & 153 & 173 & 1,177 & 961 & 373 & $96,798.45521$ & $\geq$ & $-8,192$ \\
$X_{11}$ & 0 & 0 & 0 & 0 & 467 & 2,179 & 2,801 & 2,704 & $26,444.98963$ & $\geq$ & 0 \\
$X_{12}$ & 0 & 0 & 0 & 0 & 985 & 1,743 & 2,028 & 2,810 & $21,153.56444$ & $\geq$ & $-4,096$ \\
$X_{13}$ & 0 & 0 & 0 & 0 & 276 & 675 & 1,152 & 1,009 & 8192 & $\geq$ & 8,192 \\
Obj. func. & 5,035 & 4,322 & 6,051 & 8,961 & 22,826 & 34,835 & 35,180 & 33,053 & & &
\end{tabular}

Source: Research study, 2010 
where $Y_{1}$ is $2002-2003, Y_{2}$ is $2003-2004, Y_{3}$ is $2004-2005, Y_{4}$ is $2005-2006, Y_{5}$ is $2006-2007, Y_{6}$ is $2007-2008, Y_{7}$ is 2008-2009 and $Y_{8}$ is 2009-2010.

Dual results of the primal problem shows that the feasible solution obtained in the primal problem is binding only to three sectors (food and processing industries, gypsum and cement, and automobile sectors). The rest of the sectors, which attracted FDI, can be improved by many folds. Non-binding for the rest of the sectors substantiates unbound optimal solution observed in the primal solution.

Step 7(b)

Dual optimal solution for GDP

$$
\begin{aligned}
\text { Min Annual GDP } & =573,153 Y_{1}+669,407 Y_{2}+784,254 Y_{3}+875,435 Y_{4} \\
& +1,100,987 Y_{5}+1,206,683 Y_{6}+1,235,975 Y_{7}+1,367,216 Y_{8}
\end{aligned}
$$

\begin{tabular}{|c|c|c|c|c|c|c|c|c|c|c|}
\hline & $Y_{1}$ & $Y_{2}$ & $Y_{3}$ & $Y_{4}$ & $Y_{5}$ & $Y_{6}$ & $Y_{7}$ & $Y_{8}$ & Usage & Resources \\
\hline$X_{1}$ & 644 & 532 & 721 & 1,451 & 2,614 & 1,410 & 1,677 & 875 & $330,940.753 \geq$ & $2,318.8$ \\
\hline$X_{2}$ & 326 & 269 & 469 & 581 & 4,664 & 6,615 & 6,116 & 4,185 & $282,778.435 \geq$ & -512 \\
\hline$X_{3}$ & 223 & 116 & 129 & 680 & 478 & 1,261 & 2,558 & 2,495 & $73,358.2786 \geq$ & $-3,840$ \\
\hline$X_{4}$ & 455 & 308 & 179 & 222 & 368 & 0 & 0 & 0 & $77,286.7219 \geq$ & 5,120 \\
\hline$X_{5}$ & 118 & 113 & 166 & 94 & 438 & 2,334 & 1,397 & 1,559 & $99,492.9232 \geq$ & 6,144 \\
\hline$X_{6}$ & 129 & 20 & 198 & 447 & 205 & 229 & 749 & 346 & $89,182.2524 \geq$ & 4,096 \\
\hline$X_{7}$ & 40 & 107 & 292 & 172 & 157 & 0 & 0 & 0 & $125,215.121 \geq$ & 0 \\
\hline$X_{8}$ & 37 & 111 & 38 & 42 & 49 & 0 & 0 & 0 & 16,384 & 16,384 \\
\hline$X_{9}$ & 21 & 10 & 0 & 452 & 210 & 0 & 0 & 0 & 2,048 & 2,048 \\
\hline$X_{10}$ & 47 & 12 & 192 & 153 & 173 & 1,177 & 961 & 373 & $96,798.4552 \geq$ & $-8,192$ \\
\hline$X_{11}$ & 0 & 0 & 0 & 0 & 467 & 2,179 & 2,801 & 2,704 & $26,444.9896 \geq$ & 0 \\
\hline$X_{12}$ & 0 & 0 & 0 & 0 & 985 & 1,743 & 2,028 & 2,810 & $21,153.5644 \geq$ & $-4,096$ \\
\hline$X_{13}$ & 0 & 0 & 0 & 0 & 276 & 675 & 1,152 & 1,009 & 8,192 & 8,192 \\
\hline $\begin{array}{l}\text { Object } \\
\text { func. }\end{array}$ & 573,153 & 669,407 & 784,254 & 875,435 & $1,100,987$ & $1,206,683$ & $1,235,975$ & $1,367,216$ & $352,821,059$ & \\
\hline Solution & 0 & 0 & 426.15 & 4.530973 & 0 & 12.136296 & 0 & 0 & & \\
\hline
\end{tabular}

Table 9 Dual optimal GDP

where $Y_{1}$ is $2002-2003, Y_{2}$ is $2003-2004, Y_{3}$ is $2004-2005, Y_{4}$ is $2005-2006, Y_{5}$ is 2006-2007, $Y_{6}$ is 2007-2008, $Y_{7}$ is 2008-2009 and $Y_{8}$ is 2009-2010.

\section{Conclusions and recommendations}

The study provided mathematical arguments for optimising FDI inflows to emerging market economies in the context of India. We used primal and dual LP techniques with regard to the sectoral FDI inflows to India for the period 2002-2010. The study showed that FDI inflows during the period were not optimally utilised and, consequentially, required intervention for improving its optimal solutions potentials. Given the prevailing 
economic environment and behaviour, and optimal criteria of economic agents in a particular market, it can be concluded that because primal and dual results are not the same, results obtained were not found to be optimal. It would mean that the efficiency in the market is remote possibility and substantiates that market forces do not allocate resources efficiently and follow a different pattern which can be studied on profit motives of the FDI.

Since there is sub-optimal efficiency in the FDI allocation, there is possibility to improve the allocation and productivity of the FDI. Therefore, government should work toward a sectoral allocation plan before opening or relaxing the FDI with a range of benefits for higher investment in particular sectors to balance the growth and optimise the investment.

Our findings are also in alignment with the results of other studies that indicated that the allocation of FDI to different sectors is below optimal levels and can be improved further by efficiently allocating the resources and, in turn, improve social welfare.

Policymakers' assessment of reforms is expected to adopt a scientific approach which motivates the investors to spread their investment in different sectors optimally, instead of abdicating their responsibility to market forces only. An appropriate regulatory intervention that does not influence the market forces and motivates efficient capital allocation will help the economy to be a balanced economy and manages the volatility in economic growth.

\section{References}

Altman, M. (2000) 'A behavioural theory of economic welfare and economic justice: a Smithian alternative to Pareto optimiality', International Journal of Social Economics, Vol. 27, No. 11, pp.1098-1131.

Angelo, C.F. et al. (2010) 'Determinants of FDI in emerging markets: evidence from Brazil', International Journal of Commerce and Management, Vol. 20, No. 3, pp.203-216, doi: 10.1108/10569211011076901.

Artige, L. and Nicolini, R. (2006) Evidence on the Determinants of Foreign Direct Investment - The Case of Three European Regions, CREPP Working Paper 2006/07, HEC-Management School.

Barro, R.J. and Sala-i-Martin, X. (2004) Economic Growth, Prentice-Hall of India, New Delhi.

Baumol, W.J. (2002) Economic Theory and Operations Analysis, Prentice-Hall of India, New Delhi.

Bhavan, T., Xu, C. and Zhong, C. (2011) 'Determinants and growth effect of FDI in South Asian economies: evidence from a panel data analysis', International Business Research, Vol. 4, No. 1.

Blomström, M., Kokko, A. and Zejan, M. (1994) 'Host country competition and technology transfer by multinationals', Weltwirtschaftliches Archive, Band, Vol. 130, pp.521-533.

Brook, S. (2010) A Bad Good Deal: The Challenges of Chinese Foreign Direct Investment in Africa, African Law and Development.

Candes, E. and Tao, T. (2004) Decoding by Linear Programming, Department of Mathematics, University of California, Los Angeles [online] http://www-stat.stanford.edu/ candes/papers/ DecodingLP.pdf.

Chakravarty, S. (1993) Selected Economic Writings, Oxford University Press, New York.

Chiang, A.C. and Wainwright, K. (2005) Fundamental Methods of Mathematical Economics, McGraw-Hill, USA. 
Cuthbertson, K. and Nitzsche, D. (2004) Quantitative Financial Economics: Stocks, Bonds and Foreign Exchange, 2nd ed., Wiley Publications, USA.

Dempster, M.A.H. and Hutton, J.P. (1996) Pricing American Stock Options by Linear Programming, Department of Mathematics, University of Essex [online] http://www.globalriskguard.com/resources/deriv/stockOptions2.pdf.

Department of Industrial Policy and Promotion (DIPP) (2010) Annual Report 2009-2010, Government of India, Ministry of Commerce and Industry [online] http://dipp.nic.in/fdi_statistics/india_fdi_index.htm (accessed 30 May 2010).

Fox, J. (2010) The Myth of The Rational Market: A History of Risk, Reward, and Delusion on The Wall Street, Vision Books, New Delhi.

Government of India (2010) Economic Surveys 2009-10, Oxford, New Delhi.

Hakro, A.N. and Ghumro, I.A. (2011) 'Determinants of foreign direct investment flows to Pakistan', The Journal of Developing Areas, Spring, Vol. 44, No. 2, pp.217-242.

Hillier, F.S, and Lieberman, G.J. (2010) Introduction to Operations Research, McGraw-Hill Higher Education, USA.

Ho, C.S. and Rashid, H.A. (2011) 'Macroeconomic and country specific determinants of FDI', The Business Review, Cambridge, Vol. 18, No. 1, pp.219-226, Cambridge.

Jones, C.I. (1998) Introduction to Economic Growth, W.W. Norton \& Company Ltd, London.

Joshi, V. and Little, I.M.D. (1997) India's Economic Reforms 1991-2001, Oxford University Press, Delhi.

Kolstad, I. and Villanger, E. (2008) 'Determinants of foreign direct investment in services', European Journal of Political Economy, Vol. 24, No. 2, pp.518-553.

Lawrence Jr., J.A. and Pasternack, B.A. (2004) Applied Management Science: Modeling, Spreadsheet Analysis, and Communication for Decision Making, John Wiley \& Sons, Singapore.

Lecraw, D. (1984) 'Bargaining power, ownership and profitability of transnational corporations in developing countries', Journal of International Business Studies, Spring, Vol. 15, pp.27-43.

Lewis, A. (1958) Economic Growth, Macmillan, London.

Malhotra, D.K., Russow, L. and Singh, R. (2014) 'Determinants of foreign direct investment in Brazil, Russia, India, and China', International Journal of Business, Accounting, \& Finance, Vol. 8, No. 1, p130-148.

Markowitz, H. (1952) 'Portfolio selection', The Journal of Finance, Vol. 7, No. 1, pp.77-91.

Miller, I. and Miller, M. (2008) John E. Freund's Mathematical Statistics with Applications, Prentice-Hall of India Private Limited, New Delhi.

Mohamed, Z.M. and Youssef, M.A. (2004) 'A production, distribution and investment model for a multinational company', Journal of Manufacturing Technology Management, Vol. 15, No. 6, pp.495-510.

OECD (2007) Economic Survey, Academic Foundation, New Delhi, India.

OECD (2010) Investment Policy Reviews, Academic Foundation, New Delhi, India.

Ostermark, R. (2005) 'Dynamic portfolio management under competing representations', Kybernetes, Vol. 34, Nos. 9/10, pp.1517-1550.

Panchamukhi, V.R. (1998) Contemporary International Economics, Bookwell, New Delhi.

Pradhan, R.P. (2008) 'Does economic growth promote FDI? Evidence from India and Malaysia', Southern Asian Journal of Management, January-March, Vol. 15, No. 1.

Propoi, A.I. (1976) Problems of Dynamic Linear Programming, International Institute for Applied Systems Analysis, RM-76-78 [online] http://www.iiasa.ac.at/Admin/PUB/Documents/RM-76078.pdf.

Rardin, L.R. (2002) Optimization in Operation Research, Pearson Education Asia, Delhi. 
Ravindra, A., Phillips, D.T. and Solberg, J.J. (2001) Operations Research: Principles and Practice, John Wiley \& Sons, New York.

Roubini, N. and Mihm, S. (2010) Crisis Economics: A Crash Course in the Future of Finance, Penguin Books, London.

Sharma, S. (2008) 'Analyzing the technical and scale efficiency performance: a case study of cement firms in India', Journal of advances in Management Research, Vol. 5, No. 2, pp.56-63.

Sharpe, W.F., Alexander, G.J. and Bailey, J.V. (2006) Investments, Prentice-Hall of India Private Ltd, India.

Singh, A. and Zammit, A. (1998) 'Foreign direct investment: towards co-operative institutional arrangements between the north and the south?', in Michie, J. and Smith, J.G. (Eds.): Globalization, Growth and Governance: Creating an Innovative Economy, Oxford University Press, New York.

Stiglitz, J. (1999) 'Reforming the global architecture: lessons from recent crises', Journal of Finance, Vol. 54, pp.1508-1521 [online] http://dx.doi.org/10.1111/0022-1082.00154.

Stiglitz, J. (2009) 'Moving beyond market fundamentalism to a more balanced economy', Annals of Public and Cooperative Economics, Vol. 80, No. 3, pp.345-360.

Taha, H.A. (2002) Operations Research: An Introduction, Pearson, Delhi.

Takayama, A. (2006) 'Sensitivity analysis in economic theory', Metroeconomica, Vol. 29, Nos. 1-3, pp.9-37.

Taylor III, B.W. (2008) Introduction to Management Science, Pearson, Delhi.

Wadley, D. and Smith, P. (1998) 'If planning is about anything, what is it about?', International Journal of Social Economics, Vol. 25, Nos. 6/7/8, pp.1005-1029.

Witkovsky, V. (1996) 'On variance-covariance components estimation in linear models with AR (1) disturbances', Acta Math. Univ. Comenianae, Vol. 65, No. 1, pp.129-139.

Xing, Y. (2006). Exchange Rate Policy and the Relative Distribution of FDI between Host Countries, Working paper, Research Institute, International University of Japan, EMS_2006_10.

Zavadskas, E.K., Turskis, Z., Dejus, T. and Viteikiere, M. (2007) 'Sensitivity analysis of a simple additive weight method', International Journal of Management and Decision Making, Vol. 8, Nos. 5-6, pp.555-574.

Zhang, Y. (2009) A Different Look at Inward FDI into Mainland China: An Empirical Study on Relationship of FDI and GDP and FDI Externalities on China Economic Growth, UN University, Maastricht [online] http://www.merit.unu.edu/publications/wppdf/2009/wp2009060.pdf. 